\title{
System of industrial park functioning indicators reflecting the effect of competitiveness factors of resident enterprises
}

\author{
Petr Chepur ${ }^{1}$, Aleksandr Tarasenko ${ }^{1}$, Evgeniy Tikhanov $^{2}$, Vadim Krivorotov ${ }^{2}$, and Alesya \\ Gruchenkova, ${ }^{3, *}$ \\ ${ }^{1}$ Industrial University of Tyumen, 625000 Volodarskogo Street 38, Russia \\ ${ }^{2}$ Ural Federal University named after the first President of Russia B. N. Yeltsin, 620002 Mira Street \\ 19, Russia \\ ${ }^{3}$ Surgut Oil and Gas Institute, 628405 Entuziastov Street 38, Russia
}

\begin{abstract}
Recently, industrial parks, demonstrating their effectiveness, have turned into a locomotive of business development providing the resident enterprises with a whole range of competitive advantages. In order to analyze the impact of factors enhancing the competitiveness of residents of industrial parks, the authors have developed a comprehensive system of indicators for the functioning of the industrial park which provide a quantitative assessment and a comprehensive account of the aggregate of "intra-park", local and regional factors. Considering the requirements formulated by the authors, a system of indicators for the functioning of the industrial park has been developed, which includes two structural blocks: indicators of the industrial park performance and indicators of the industrial park's base area potential. Options of practical use of the formed system of indicators are proposed, on the one hand, to establish targets for further development of the industrial park based on the comparison of the studied industrial park with the projects of competitors, and on the other hand, to design an industrial park development program that ensures the competitiveness of the site residents.
\end{abstract}

\section{Introduction}

The positive experience of many Russian regions over the past decade indicates that industrial parks at the current stage of the country's economic development play a significant role in ensuring the dynamic growth of direct investments in the modernization of industry, creating conditions for the organization of new competitive production. This allows us to consider industrial parks as a locomotive of business development, creating an effective platform for sustainable long-term growth of the industrial complex of a particular region. At the same time, it should be noted that industrial parks provide enterprises that host production on their territory with a whole range of advantages, the key ones being the proximity of sales markets and labor resources, transport accessibility, simplified procedure for residents to pass

\footnotetext{
*Corresponding author: alesya2010-11@yandex.ru
} 
administrative and licensing procedures, supply with energy resources and advanced engineering solutions [1-6].

Considering the aforesaid, we note that resident enterprises of industrial parks are influenced by many factors that have a positive impact on their level of competitiveness [7, 8, 9-12].

The whole aggregate of these factors can be divided into three blocks according to their territorial character (Figure 1): "intra-park" factors (conditions created within the boundaries of a specific investment site), local factors (advantages of the territory in the immediate vicinity of the industrial park) and regional factors (preferences for production location on the territory of a certain subject of the Russian Federation) [13-14]. At the same time, the impact of these factors on the competitiveness of enterprises can be assessed and analyzed solely on the basis of a system of quantitative indicators characterizing their impact. This actualizes the problem of determining and evaluating a set of basic indicators of the functioning of industrial parks and studying their impact on the level of competitiveness of economic entities.

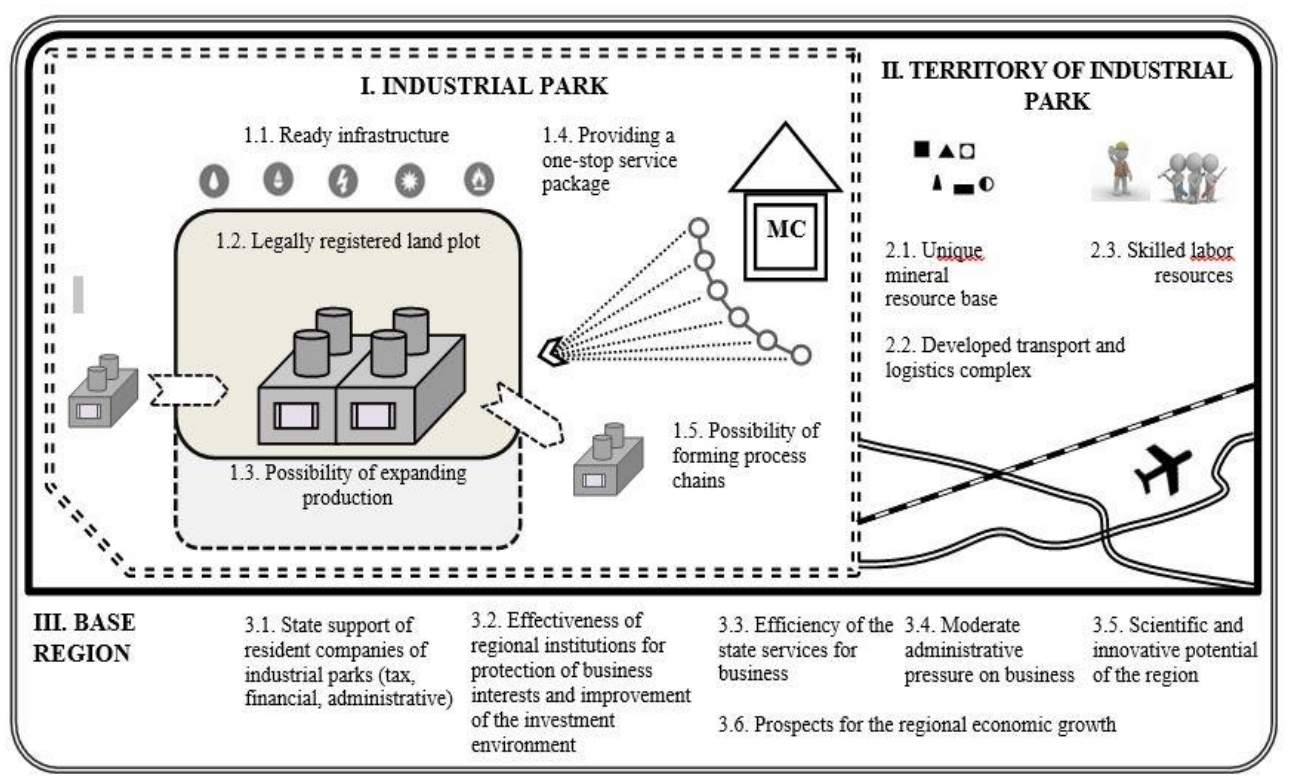

Fig. 1. System of factors of increasing the competitiveness of enterprises operating on the territory of an industrial park.

To consider the diversity of characteristics of the activity of industrial parks, it is necessary to form an integrated system of indicators of their functioning, the key requirement of which is to ensure a comprehensive accounting of the above-mentioned factors of increasing the competitiveness of enterprises operating on the investment site.

\section{Methods}

In practice, the entity interested in analyzing the system of indicators of functioning of an industrial park to develop a set of management impacts aimed at increasing the attractiveness of the site for potential investors is its management company. In addition, such an analysis makes it possible to formulate a program for the development of an industrial park, considering the needs of resident enterprises already operating on its territory, which contributes to the creation of favorable conditions for their further growth. 
In this regard, the system includes indicators of the functioning of an industrial park, meeting the following basic requirements:

— indicators should be calculated on the basis of the industrial park management data available to the management company;

- the management company should be able to directly or indirectly influence the change in indicators;

— indicators should characterize the activity of an industrial park in dynamics and enable analysis of its development trend.

At the same time, it should be noted that the system of indicators of the functioning of an industrial park is open and, depending on the individual features of the site and the volume of available initial data, experts can supplement the necessary set of indicators.

The classification of indicators of the functioning of an industrial park assessing the impact of factors of competitiveness of enterprises operating on its territory is based on their differentiation into two blocks:

- a block of indicators of the industrial park performance reflecting the impact of a complex of "intra-park" factors;

- a block of indicators of the industrial park's base area potential reflecting the impact of a complex of local and regional factors.

The blocks include several groups of indicators, each of which has main and additional indicators. Division of indicators into main and additional is carried out according to the degree of their importance (primary or secondary) from the position of influence on the level of competitiveness of resident enterprises of the industrial park. Main indicators provide the most comprehensive assessment of competitiveness factors, additional indicators allow us to assess individual aspects of the manifestations of the impact of the factors under consideration $[15,16]$.

The system of indicators of the functioning of an industrial park proposed by the authors, which assess the influence of factors of competitiveness of enterprises operating on its territory, is includes seven groups of indicators.

I. Performance of the management company of the industrial park:

1.1. Share of revenue of the management company from managing the functioning and establishment of the industrial park in the total volume of revenue;

1.2. Coefficient of return of expenses of the management company on primary activities;

1.3. Activity coefficient of expanding activities of the management company;

1.4. Labor productivity of employees of the management company.

II. Quality of the infrastructure support of the industrial park territory:

2.1. Average level of loading of the infrastructural capacities of the industrial park;

2.2. Average degree of wear of the industrial park infrastructure;

2.3. Average rate of growth in tariffs for energy resources consumed by the residents of the industrial park;

2.4. Volume of capital investments in the development of the industrial park per 1 ha of the territory provided with a new infrastructure. Level of the infrastructure provision of the industrial park territory;

2.5. Level of the reserve of the territory provided with infrastructure for the further development of the industrial park;

2.6. Level of accidents in the engineering networks of the industrial park.

III. Degree of the industry specialization and cooperation potential of the industrial park:

3.1. Level of specialization of the industrial park in certain activities;

3.2. Level of co-production in the industrial park;

3.3. Indicator of the number of orders carried out in the order of cooperation between the resident enterprises of the industrial park.

IV. Level of the personnel and scientific potential of industrial park's base area: 
4.1. Share of employees of enterprises resident in industrial park with higher professional education;

4.2. Share of employees of enterprises resident in the industrial park who received additional training in the framework of targeted educational programs;

4.3. Ratio of the share of innovation and $R \& D$ expenditures in the revenues of enterprises resident in the industrial park to the share of innovation and $R \& D$ expenditures in the territory of the subject of the Russian Federation in GRP;

4.4. Ratio of the average wage at enterprises resident in the industrial park to the average wage in the territory of the industrial park;

4.5. Ratio of supply and demand in the labor market of the territory of the industrial park;

4.6. Unemployment rate in the territory of the industrial park.

$\mathrm{V}$. Level of the natural resource potential of the industrial park's base area:

5.1. Distance ratio of the industrial park residents from places of concentration of mineral resources;

5.2. Level of provision of the industrial park base territory with reserves of natural and technogenic mineral resources.

6. Level of the transport and logistics potential of the industrial park's base area:

6.1. Distance ratio of the industrial park residents from the main areas of sales of products;

6.2. Indicator of the development of a network of motor roads with a hard surface and railway tracks in the industrial park base territory.

7. Level of the investment potential of the base region of the industrial park:

7.1. Amount of state support given to residents of the industrial park;

7.2. Average level of tax burden on the residents of the industrial park;

7.3. Growth rate of the regional economy;

7.4. Growth rate of the number of inspections in respect of legal persons and sole entrepreneurs in the region;

7.5. Growth rate of the time spent in the region for administrative procedures.

\section{Results and discussion}

I. Performance of the management company of the industrial park. The group unites indicators that in one way or another characterize the quality and efficiency of how the managing company provides the residents of an industrial park with a one-stop service package. Given that the pricing policy of the management company, the balance of the range of services it provides, as well as their compliance with the real needs of the residents of the site have a direct impact on the financial and economic performance of production on the territory of the industrial park, this group of indicators is of paramount importance in terms of the impact on the level of competitiveness of the resident enterprises.

II. Quality of the infrastructure support of the industrial park territory. The second group consists of indicators that characterize the use of the main asset of the industrial park engineering, transportation and production infrastructure facilities. Considering the fact that the ready infrastructure is the key advantage of industrial parks as a form of organization of investment sites, the group of indicators should be considered as a priority when analyzing the activities of the industrial park.

Effective and smooth operation of engineering networks, availability of a reserve of infrastructure capacities, balanced cost of energy resources are the key to the stable and efficient operation of enterprises within the boundaries of an industrial park. Indicators of infrastructure support of an industrial park determine the time and financial expenditures of resident enterprises at the stage of setting up production, having a significant impact on the level of current production costs. 
III. Degree of the industry specialization and cooperation potential of the industrial park. This group includes indicators reflecting the potential of the industrial park for residents in terms of the possibility of forming long-term economic relations, conducting joint or technologically related production activities. The possibility of building cooperative ties between companies operating on the territory of the industrial park in the industrial sectors that are relevant to the industrial park contributes to stabilizing the demand for products produced by the residents, increasing the efficiency of using production capacities, and deepening the specialization of the residents' production facilities.

A result of this is optimization of production processes, increase in the quality of products and labor productivity, lower costs and higher profitability of the activities of resident enterprises.

IV. Level of the personnel and scientific potential of the industrial park's base area. This group combines indicators characterizing the provision of the territory in the area of the industrial park with labor resources, including highly qualified ones, the degree of development and quality of the education system, the level of development of the scientific and technical sphere, and the innovative and intellectual potential of the territory.

High labor, scientific and technical potential of the territory gives the residents of the industrial park the opportunity to staff the production of professional workers in the conditions of high competition in the labor market, with a constant improvement of their skills, effective implementation of research and development and innovative solutions in production [17-19].

V. Level of the natural resource potential of the industrial park's base area. This group includes indicators characterizing the supply of the territory adjacent to the industrial park with mineral reserves and technogenic mineral resources that may be involved in economic circulation and largely determine the industry profile of the industries that are promising for developing production on the given territory.

The proximity of the raw materials base allows minimizing the time costs for transportation and preliminary processing of raw materials, saving on logistics costs, which ultimately gives enterprises the opportunity to establish a competitive price for the products sold.

VI. Level of the transport and logistics potential of the industrial park's base area. This group of indicators from various sides characterizes the location of the territory of the industrial park in relation to the transport network, the degree of development of which has a great influence on the prospects for the successful operation of enterprises within its boundaries. Logistic connectivity of the territory provides an opportunity for a rapid, unhindered and cost-effective exchange between economic entities, and the proximity of markets allows companies to realize the finished products at minimum costs and in optimal terms.

VII. Level of the investment potential of the base region of the industrial park. The last group of indicators characterizes the degree of favorable investment climate on the location of the industrial park location, conditions created in the region for business, and instruments for supporting investment activities. The effectiveness of the provision of public services for businesses, the degree of administrative pressure on entrepreneurs, the diversity and accessibility of various types of financial and non-financial support to the residents of industrial parks, and the level of investment risks largely determine the stability, predictability and prospects for the development of resident companies in the industrial park.

The proposed system of indicators of the functioning of the industrial park allows management companies to carry out a comprehensive analysis of the activities of the investment site in dynamics, as well as its key advantages and disadvantages. On the one hand, management companies have an opportunity to compare the values of certain performance indicators of the industrial park with similar indicators of competitor sites, 
thereby identify indicators that need improvement and establish targets for further development.

On the other hand, the developed system of indicators, reflecting the impact of a complex of factors of competitiveness of resident enterprises of industrial parks, can be used to formulate an industrial park development program, the final goal of which will be a growth in competitiveness of the residents of the site.

\section{Conclusions}

As a result of the work, key factors for increasing the competitiveness of resident enterprises of industrial parks have been identified. A set of requirements for the content of the system of indicators of functioning of an industrial park has been determined and justified. The system of indicators of functioning of an industrial park that assess the influence of factors of competitiveness of enterprises operating on its territory has been developed, which includes two structural blocks: indicators of the industrial park performance and indicators of the industrial park's base area potential. It is emphasized that the formed system of indicators is open in nature and, if necessary, can be supplemented by the necessary set of indicators.

The directions of practical application of the developed system of indicators of functioning of industrial parks are proposed: comparison of the studied industrial park with competing sites for establishing targets for further development of the industrial park, as well as the formation of an integrated program for the development of an industrial park aimed at increasing the competitiveness of the residents of the site.

\section{References}

1. V.V. Krivirotov, I.V. Ershova, I.S. Belik, Konkurentosposobnost' sotsial'noekonomicheskikh sistem: vyzovy novogo vremeni (Economika, Moscow, 2014)

2. V.V. Krivirotov, A.V. Kalina, T.V Matveeva, A.Yu. Bayranshin, Povyshenie konkurentosposobnosti sovremennykh rossiyskikh territorial'no-proizvodstvennykh kompleksov (Ural State Technical University, Yekaterinburg, 2013)

3. V.V. Krivirotov, A.V. Kalina, V.D. Tretyakov, E.A. Tikhanov, K.E. Parfenov, Vestnik of the Ural Fed. Univ. 4, 61-76 (2013)

4. V.L. Belousov, Analiz konkurentosposobnosti firmy (Marketing in Russia and abroad, Moscow, 2007)

5. K.G. Borodin, Konkurentosposobnost'v rynochnoy ekonomike (Teis, Moscow, 2006)

6. V.A. Bykov, T.G. Filosofa, Konkurentsiya. Innovatsii. Konkurentosposobnost' (Uniti, Moscow, 2008)

7. V.V. Krivirotov, A.V. Kalina, E.A. Tikhanov, S.E. Erypalov, Vestnik of the Ural Fed. Univ. 2, 61-74 (2014)

8. V.V. Krivirotov, Metodologiya formirovaniya mekhanizma upravleniya konkurentosposobnost'yu predpriyatiya (Ural State Technical University, Yekaterinburg, 2007)

9. L.G. Iogman, M.A. Gusakov, The Region's Econ. 4, 85-94 (2007)

10. E.M. Korotkov, Menedzhment (INFRA-M, Moscow, 2010)

11. V.P. Zotov, Kompleksnyy ekonomicheskiy analiz khozyaystvennoy deyatel'nosti (Kemerovo, 2009)

12. R.E. Mansurov, Market. in Rus. and abroad 2(25), 91-94 (2006) 
13. A.L. Denisova, N.V. Ylyakhin, Upravlenie konkurentosposobnost'yu promyshlennogo predpriyatiya: aspekty kachestva (Tambov state technical University, Tambov, 2006)

14. T.Yu. Ivanova, V.I. Prikhodko, Teoriya organizatsii (KnoRus, Moscow, 2010)

15. A. Shulus, Investm. in Rus. 12, 11-19 (2012)

16. E.I. Mazilkina, G.G. Panichkina, Upravlenie konkurentosposobnost'yu (Omega-L, Moscow, 2007)

17. O.V. Savinova, M.A. Istrashkina, Econ. of ed. 5, 135-152 (2012)

18. A.Yu. Yudanov, Konkurentsiya: teoriya i praktika (Gnom-Press, Moscow, 2009)

19. A.A. Anfinogentova, M.N. Dudin, N.V. Lyasnikov, O.D. Protsenko, Economy of Region 14, 638-650 (2018), doi:10.17059/2018-2-24 